\title{
The Riverside/Regensburg exchange
}

\section{Catalog librarians from California and West Germany trade places for six months.}

\section{The Regensburg exchange}

\author{
By Heidi Hutchinson \\ Cataloger \\ University of California, Riverside
}

For six months during 1988, I had the unique opportunity to trade jobs with a German librarian. From March 1 to August 31, I worked at the University Library at Regensburg, West Germany.

It all began in October 1986, when the new UC Riverside university librarian Jim Thompson offered the librarians on his staff the chance for a sixmonth job exchange with a librarian in a foreign country. The choice of country was open to the individual. I was the first to volunteer, with the wish to work in Scotland. Of the ten Scottish librarians we wrote to, nine of them sent regrets that an exchange would not be possible from a staffing and economic standpoint at the time. One university librarian made an offer, but it did not concur with Riverside's needs.

Jim did not want me to give up, however, and asked where else I would wish to go. With my background, education, knowledge of the lan- guage, and interest in German librarianship, I chose the Federal Republic of Germany. This time we targeted twice as many potential exchange partners.

Our method was as follows:

I chose the names and addresses of twenty large academic libraries out of the World of Learning and the VdB Jahrbuch, the yearbook of one of the German library associations, and Jim wrote a letter, which I translated into German, to each of the library directors. We thought that addressing them in their own language would convey to them our willingness to meet them more than half way. An excerpt from Jim Thompson's letter shows our basic intent:

"I am writing in my capacity as Director of the University Library of the University of California, Riverside. A member of our staff, Heidi Hutchinson of the Cataloging Department, is seeking an 
exchange opportunity in Germany and has asked that I contact you to inquire whether your staff might include a librarian who would wish to consider this possibility.

"Such an exchange would provide the two participants with an extraordinary opportunity for studying academic and library practices in another country, and would bring to each host library a new perspective. Generally in such exchanges each librarian is considered to be on assignment, and receives salary, from his or her home library; this eliminates much of the bureaucratic difficulty an exchange would otherwise entail. An exchange of six months would be ideal, but one of a different duration would also be desirable."

The letter then told something about me and about the attractions of Southern California, where UC Riverside is located.

Twenty letters went out in July of 1987. The libraries we approached were the university libraries at Augsburg, Bonn, Bremen, Frankfurt, Freiburg, Giessen, Göttingen, Hamburg, Heidelberg, Konstanz, Marburg, Regensburg, Tübingen, and Würzburg; and the state libraries at Berlin, Frankfurt (Deutsche Bibliothek), Hannover, München, Stuttgart, and Wolfenbüttel.

This time the response was overwhelmingly favorable. Replies came back within six weeks from all but two of the library directors. All 18 respondents, even those who regretted not being able to take us up on our offer, showed interest in the project, and wished us well. Reasons given for not participating in an exchange were either a shortage of personnel, no one in their library was interested, or University restrictions on exchanges.

Ten libraries were willing to try an exchange, an embarrassment of riches indeed!

Several libraries, even upon their first response to our letter, already had a potential exchange librarian lined up. A few of these began to correspond with me personally, so that we soon had letters going back and forth between the two countries on two levels, between the directors and the exchange librarians! At this point, the offer from the University Library at Regensburg in southeast Bavaria began to "take the lead."

\section{Regensburg is chosen}

Our letter had been posted or circulated, and a cataloging librarian had stepped forward interested in the exchange. I was particularly pleased when Lisa Hampel wrote to me in fine English, not only overflowing with enthusiasm for the opportunity to come to California, but also anxious to make me want to come to her town. She had enclosed in her letter the most beautiful color travel brochures of Regensburg and surroundings.

The question of an actual work permit was alle- viated by UCR's original proposal that we would both retain our salaries from our home institutions during the foreign stay. This simplified the procedure considerably, eliminating much of the bureaucratic difficulty an exchange would otherwise entail. I suspect that this simplification was one of the factors that made the exchange attractive to so many German libraries.

In 1988, I was slightly worried about the value of my dollar, at an all-time low against the German mark. Again, this was probably one of the factors that made the exchange idea attractive to the German side. Travel and housing would be the major expenses to anticipate. Once we had established that we could actually trade living quarters as well as jobs, Lisa Hampel and I decided to continue to pay the rent or mortgage on our own homes during our absence. As so many things are in Germany, hers was automatically deducted from the paycheck that was automatically deposited into her checking account. I prepaid six months on my house payment before leaving California.

The housing locations turned out to be astonishingly convenient: both of us lived within a mile of our respective libraries and walked or bicycled to work each day. Lisa did not own a car, and I was not interested in driving in Europe anyway. On her part, she made very little use of my vehicle while here, although I did make it available to her.

One expense we did agree to carry ourselves as it was incurred was the telephone bill.

\section{Flight arrangements}

Both of us made sure we got a good discount rate on our airline tickets. We were both reimbursed for that initial travel cost, in my case by the Friends of the UC Riverside Library, Lisa by a German government agency. After corresponding and telephoning with one another, we decided that we needed to meet one another, and so Lisa made arrangements to arrive in Riverside four days before my departure. I was able to introduce her to the Library staff, and we were even treated to a joint hail-and-farewell party on my very last day.

It was nice to be able to show her around Riverside and the University myself, but even when I left, I knew Lisa was in very good hands with the UCR Library's cataloging department staff.

My first personal connection in Regensburg, on the other hand, was Lisa's parents, who also lived in town, and who picked me up at the train station and took me to Lisa's apartment, handing over the keys to what would be my home for the next six months.

\section{An introduction to the library}

The very next morning I began working at the Regensburg Library. I was greeted at the informa- 
tion desk by a friend designated by Lisa, and taken to the Director's office.

On my first day there, I was issued my time-clock card, endowed with three weeks of vacation (the proportionate amount for a person in service for six months), and instructed in the meticulous timekeeping procedures in place at Regensburg. This proved to be the first indication that I was not to be treated as a guest with special privileges, but as a real staff member, a facet of the exchange I grew to appreciate very much. I am sure it aided my acceptance as a colleague more than any other single factor, save perhaps my fluency in the German language.

My first library day consisted in my being shown around the public services sections of the library and introduced to my colleagues in the cataloging department. I was sent forth to City Hall in the afternoon, as it was imperative that I register as a resident (which all Germans and foreigners living in Germany do) as soon as possible. In addition, I needed to obtain the special stamp in my passport, the Aufenthaltserlaubnis, that gave me permission as an alien to remain in the country for the duration of my exchange.

\section{The Cataloging Department}

Back at work, it was decided that I would become an integral part of the descriptive cataloging unit, since that is where at least part of my expertise lies, and in fact, I was able to take over Lisa Hampel's desk and her cataloging area of Theology. For several weeks, I was in training, learning to catalog in an offline system using the German ISBD rules called RAK-WB. I was gratified to find that, being ISBD, the rules had many similarities to AACR2, and after three weeks I was to the point where only an occasional cataloging record would have to be checked.

I was so fascinated with the cataloging process at Regensburg as compared to UC Riverside that I created a slide program on it to take back and show to my fellow catalogers at home.

Naturally, I was also interested in subject analysis, and since this is done separately from the descriptive cataloging, I was given permission to "intern" in the other departments involved with that. This meant I was able to work with two different subject specialists, called Fachreferenten, who in Germany are librarians with Ph.D.s in other subject areas. They are generally responsible for collection development, faculty contact, classification, subject heading assignment and online literature searching in their areas of expertise, among other things.

The second department involved with subject cataloging was a subject heading quality control unit, where I served for several weeks half-time, keeping up my primary job in the descriptive cataloging unit the rest of the time.

I found that returning to descriptive cataloging between visits elsewhere was particularly important for my sense of belonging. This was the group that had generally accepted me as "one of theirs," and I really needed that acceptance to feel at home.

\section{Time away}

My excursions outside of my regular department did not commence until after I had served for six full weeks and established myself as a viable member of the cataloging unit. My program of training and informational visits was developed with the assistant library director in conjunction with my unit supervisor. It eventually included visits of varying lengths to other departments within the library, visits to the other Regensburg libraries and to two further university libraries in the Bavarian region, at Augsburg and Eichstätt. These were often arranged either by the library or by me in cooperation with the library administration.

Release time was generously granted to me for library visits as well as my participation in the German Library Conference in Berlin in May 1988. This proved to be one of the highlights of my exchange. The conference was very impressive and informative. A visit to the State Library in Berlin was also included.

Other activities I undertook on my own time, that is, in the three weeks of vacation with which I was endowed. These included a trip to Scotland in June to attend the Scottish Library Association Annual Meeting and a week-long tour "North" that included visits to the German National Library (Deutsche Bibliothek) and the University Library in Frankfurt, the University Library at Braunschweig, the Herzog-August Bibliothek in Wolfenbüttel, and the Otto Harrassowitz Company in Wiesbaden. At all of these I was graciously received as an honored guest-perhaps a reflection on the status of American librarianship abroad.

I also needed some vacation time to pursue a grant project I had brought with me from home, which involved travel to Vienna for a total of six days.

Time off was another administrative area in which UCR Library and UB Regensburg found a very satisfactory solution for me. For true vacation time, I applied according to Regensburg's guidelines. I kept track of it on a specially devised tally sheet from my personnel office at UCR (this was also true for sick leave), reporting it back all at once in the month of September when I arrived home. Release time for library-related activities was granted generously from both sides, because visiting and learning about other libraries was by its very nature a major part of the whole exchange concept.

\section{8 / C\&RL News}


Some things are more timely than others...

\section{DISCOVER THE WORLD OF LIBRARY AND INFORMATION SCIENCE with Library Times International}

a timely bimonthly journal offering a unique single source for:

- World News

- Information Science Update

- Provocative Interviews

- Probing Editorials

- Special Reports on Conferences

- New Publications

- Calendar of National and International Conferences

- Book Reviews

- Articles

- And Much More ...

There is no better medium than Library Times International to reach the library and information science world. It is the only journal which brings librarians, library educators, information scientists and others together from all continents. Recommended by Library Journal.

Subscription rates: $\mathbf{\$ 2 2 . 0 0}$ for institutions; $\mathbf{\$ 1 6 . 0 0}$ for individuals, foreign subscribers add $\$ \mathbf{1 0 . 0 0}$ for airmail and $\$ \mathbf{5 . 0 0}$ for surface mail.

Free sample copies are available.

Send orders to:

Library Times International, Subscription Department, P.O. Box 15661, Evansville, Indiana 47716, U.S.A. 


\section{Records of the exchange}

At the end of my six months, which flew by much too quickly, the UB Regensburg library administration and I jointly developed two documents. The first was a detailed month-by-month account of my activities, which I compiled and later translated into English to add to my personnel file. A copy stayed with the library administration as well as with each person who supervised me at Regensburg. This document was important in justifying the usefulness of the exchange, and can serve as a model for the types of activities that are possible when visiting a foreign library.

The second document was a letter from the library director at Regensburg to our library director at UCR, containing his thoughts on the success of the exchange. This was, again, translated by me and sent to Riverside, arriving home before I did. One of the points that was consistently emphasized was how much the Regensburg staff appreciated my command of the German language. They decided to make it a prerequisite for foreign visitors who stayed for more than just a day-long visit, having appreciated the efficiency of being able to explain things once and being understood.

\section{Conclusion}

In summary, I think this experience proves that such an exchange can be carried out successfully with a minimum of bureaucracy and complication, but is most likely to succeed if both librarians truly place an emphasis on entering the daily worklife in the new situation, rather than approaching it as primarily a research sabbatical. The most important practical considerations that contributed to the success of this particular exchange, aside from remaining on the home salary, were the exchange duration of six months, the language fluency on both parts, and the close match in interest areas, that is, trading a cataloger for a cataloger.

\section{The Riverside exchange}

\section{By Elisabeth Hampel}

\author{
Cataloger \\ Regensburg University, West Germany
}

In early August 1987 I had just returned from a wonderful vacation in America there was a letter being circulated in Regensburg University Library. An American librarian was looking for a German exchange partner. What a wonderful idea!

At our library there were three librarians interested: a reference librarian, one from Collection Development, and a cataloger. The reference librarian withdrew her application, so finally the library director wrote back to the initiator of the exchange, Jim Thompson, university librarian at the University of California, Riverside, that there were two German librarians eager to go to Riverside.

Heidi Hutchinson, the American librarian interested in the exchange, worked in the cataloging department at UC Riverside Library. In his return letter, Jim Thompson said that ideally he would like to have another cataloger come in Heidi's place, and he added Heidi's home address.

At this time (September 1987), I, the Regensburg cataloger, thought it might help to work things out if we communicated directly, so I wrote to Heidi while Dr. Niewalda, my boss, kept in touch with Jim Thompson.
Unfortunately, Heidi was very busy preparing for her final exams for her master's degree in German, so it was mid-December by the time she replied. I had lost all hope by then, and her letter discouraged me even more, because she told me that she was negotiating with a second German library at the same time. So I returned to everyday life. But then, on the Sunday before Christmas, I got a telephone call from Heidi asking if I might still be interested. Well, I was not only interested, I was delighted, although my knees shook when I realized that I would be going-all alone-to America.

In our phone conversation we also agreed on the beginning date for the exchange that had been suggested by Dr. Niewalda, March 1, 1988. This left only two months for preparations. Both libraries exchanged administrative letters in order to get us grants for the trip. In addition, I had to get permission from the agency that owns my apartment to make it available for my exchange partner.

I went to the U.S. Consulate-General in Munich for a visa, only to learn that my tourist's visa was fine, as the exchange was for six months and I would not be earning money in the States. Our administrations had agreed to continue paying each em- 
ployee's salary, which was another step in simplifying the exchange. All I needed in the States was my credit card, and I did not need a work permit.

The expensive air fare was paid by Regensburg University, and so, on February 25, 1988-in dreadful weather-I left Munich for sunny California.

Heidi met me at the airport in Ontario, California. She had postponed her departure so that we could actually meet each other. So far we only knew each other's voices. Heidi showed me around in Riverside and in the library, and I was invited to a "potluck party" (the first new American idiom for me) at my new supervisor's house. Here I met many of my new fellow librarians, and they made me feel at home at once.

On Saturday night Heidi and I joined UCR's head of public services for a trip to Los Angeles and a concert by the Los Angeles Master Chorale, the beginning of many wonderful trips on which my new friends took me. This was my first impression of Americans: warm, helpful, and friendly people, and this impression has lasted ever since.

On February 29, Heidi left, and I felt life getting serious. I went to work at UCR for the first time, was introduced to my new colleagues in Technical Services, and right away I began learning the fundamentals of online cataloging on an OCLC terminal.

My aim was to learn as much about automated systems as possible, because our cataloging network back home was going online, too, in the next few years. I was also interested in CD-ROM, of which UCR has a good selection. I still keep in contact with one of the reference librarians who does a lot of research in this field.

I soon developed a routine in searching books on OCLC and also on MELVYL, the online catalog of the UC System. Every morning I would search newly arrived books, and I learned how to edit and produce records.

In order not to feel homesick (although there was no danger), I cataloged German books. It was very interesting to compare how AACR2 and RAK (the German cataloging rules) handled the same materials. In addition, I helped the humanities bibliographer check the new German approval books-a task which I enjoyed very much.

I spent some time at the Eighteenth-Century Short-Title Catalog (ESTC). This is not a department of UCR Library, but it is housed there. It is the North American coordination agency for this Anglo-American initiative to create a supplement to the short title catalogs of Wing and Pollard and Redgrave. ESTC is a member of the RLIN network, and from recent publications I have learned that ESTC was one of the first databases in the Linked Systems Project.

On April 13 there was a big event: the Cataloging
Department took me to Disneyland! It was wonderful. Afterwards a few of us went to the Anaheim Stadium to watch a California Angels baseball game-and this started a real baseball addiction in me. I am trying to keep track with baseball in Germany, and I am pleased to see that the Angels are doing extremely well as of this writing.

In May I took a trip, kindly granted by Jim Thompson, to OCLC, which I regard as one of the high points of my exchange program. For three days I was guest at the OCLC Headquarters in Dublin, Ohio. I realized how much German librarians still have to learn concerning professionalism and library automation.

Another climax was the ALA meeting in New Orleans. It impressed me so much that I returned this year to Dallas (of course there are meetings in Germany, too, but with only about 3,000 participants and a printed program of twenty pages!) I have become a member of ALA, and I hope I will be able to attend many more of these meetings in the future.

Back at UCR, I visited all other departments, learned how to handle the INNOVACQ acquisitions system, CLSI circulation system, and OCLC interlibrary loan susbsystem. So I learned as much as possible about automated systems. And I ob-

\section{Cooperative Research Grant Program}

The Council on Library Resources, Washington, D.C., invites applications to the Cooperative Research Grant Program. Each year the Council makes a limited number of grants to support research projects proposed jointly by librarians and members of faculties in library science or other appropriate disciplines. This program is designed to stimulate productive communication between teaching faculty and librarians, to encourage librarians to develop more fully their research skills, and to increase the quantity and improve the quality of libraryrelated research. Cooperative research grants are given for well-designed projects that exhibit an imaginative approach to solving problems or analyzing subjects of current interest to libraries. Grants made to librarian-faculty teams are limited to a maximum of $\$ 3,000$ and are intended to fund direct costs incurred in the conduct of the research project. Grants are awarded twice each year: the spring deadline is April 1; the fall deadline is November 1. For more information contact: Cooperative Research Program, Council on Library Resources, 1785 Massachusetts Avenue, N.W., Suite 313, Washington, DC 20036; (202) 483-7474. 
served that the service the patrons get is excellent. German librarians could learn there, too.

That is still not all I saw. I visited the University of Arizona at Tucson Library, with its sophisticated GEAC system, the research libraries at UCLA and UC Berkeley, and Riverside Public Library. I wish my home town had a public library like that!

Looking back, I can say I have learned a lot about American libraries as well as about the American way of life. But the overwhelming experience was the friendliness and kindness of all the people I met.

\title{
The 1989 Annual Conference of
}

\section{German Librarians}

\author{
By Siegfried Feller
}

Chief Bibliographer

University of Massachusetts

\section{Our German counterparts meet in Bonn.}

H

eld this year on May 18-20 in West Germany's capital city, Bonn, the Annual German Librarians' Conference (Bibliothekartag) is sponsored jointly by the Verein deutscher Bibliothekare ( $\mathrm{VdB}=$ Association of German Librarians) and the Verein deutscher Diplom-Bibliothekare an wissenschaftlichen Bibliotheken $(\mathrm{VdDB}=$ Association of German Certified Librarians at Scholarly Libraries). Germany has two strata of professional librarians, and although this is a slight oversimplification, members of the VdB hold a Ph.D. or terminal graduate degree in one of the sciences, followed by a program of education with certification as librarian. VdDB members take professional education and training as librarians (two or more years), usually after matriculating from a gymnasium, without completing a university Ph.D. program. Paraprofessional organizatiøns are also invited to participate in the Bibliothekartag (a fairly recent development), but as yet, they do not attend in large numbers. The typical Bibliothekartag can be compared with our ACRL meetings, in terms of programs and attendance; nearly all of the participating librarians are from academic and research libraries (which includes most of the state libraries and a few public libraries). Every fifth year (most recently in West Berlin, 1988) there is a Kongress, which more closely resembles the summer ALA conference, with participants from libraries of every type and size invited.

There is always a host institution-usually a university-whose facilities are made available for conference/lecture rooms, exhibitors, and various amenities. Library staff of the host institution devote considerable time and effort in planning and preparation for most of the year before the event; they are assisted by volunteers from other nearby libraries, some of whom may act as co-hosts for selected activities, and to some extent by state and local authorities. Municipal auditoriums and other facilities are usually also used, for program presentations, receptions, and other ceremonies, and 